\title{
PENGUATAN ASPEK PRODUKSI DAN PEMASARAN PADA USAHA KERIPIK SINGKONG MIX SAYUR
}

\author{
STRENGTHENING THE PRODUCTION AND MARKETING ASPECT IN \\ CASSAVA MIXED VEGETABLE CHIPS
}

\author{
${ }^{1)}$ Annisa Kesy Garside, ${ }^{2)}$ Teguh Baroto, ${ }^{3)}$ Ode Rapija Gunarimba Waibo \\ ${ }^{1,2)}$ Program Studi Teknik Industri, ${ }^{3}$ Program Studi Teknik Sipil \\ Universitas Muhammadiyah Malang \\ Jl. Jalan Raya Tlogomas No. 246 Malang, Jawa Timur
}

Email: annisa@umm.ac.id

\begin{abstract}
ABSTRAK
Bunda Mandiri merupakan usaha kecil yang membuat keripik singkong mix sayur dengan merek "Singtoss". Permasalahan dari aspek produksi adalah waktu pemipihan adonan keripik masih lama karena menggunakan mesin penggiling manual. Selain itu, pemilik usaha berkeinginan untuk memasarkan produk ke toko oleh-oleh yang tersebar banyak di wilayah Malang, namun terkendala dengan adanya persyaratan toko yaitu mewajibkan produk memiliki PIRT dan sertifikat halal MUI. Oleh karena itu tujuan program kegiatan pengabdian masyarakat ini adalah melakukan inovasi proses untuk mempercepat waktu pemipihan adonan dan meningkatkan pemasaran produk dengan menciptakan keunggulan melalui produk halal. Kegiatan dilakukan melalui difusi teknologi proses produksi dan pengemasan produk serta advokasi dalam bentuk pendampingan pengajuan sertifikasi halal dan pengoperasian mesin. Hasil yang diperoleh dari kegiatan PKM adalah penggunaan mesin penggiling adonan keripik dalam proses produksi, desain kemasan yang baru dengan mencantumkan logo halal MUI, peningkatan pengetahuan pemilik usaha mengenai proses sertifikasi halal dan desain kemasan, serta peningkatan ketrampilan dalam mengoperasikan mesin penggiling. Keberhasilan kegiatan ini dapat diukur dari peningkatan kuantitas produksi dari $6 \mathrm{~kg} / \mathrm{hari}$ menjadi $14 \mathrm{~kg} / \mathrm{hari}$ atau naik $150 \%$. Selain itu omzet penjualan produk naik 1,5-2 kali lipat dibandingkan kondisi awal.
\end{abstract}

Kata kunci: Mesin Penggiling; Singkong; Keripik; Halal; Kemasan

\begin{abstract}
Bunda Mandiri is a small business that makes vegetable mix cassava chips under the brand name "Singtoss." The problem with the production aspect is that the time for flaking the dough is still long because it uses a manual grinding machine. Also, business owners want to market their products to souvenir shops scattered throughout the Malang area but are constrained by the store's requirements, which require the product to have a PIRT and MUI halal certificate. Therefore, this community service program aims to innovate processes to speed up the time of the dough flakes and increase product marketing by creating excellence through halal products. The activity was carried out through technology diffusion of the production process and product packaging and advocacy in the form of assistance for the submission of halal certification and machine operations. The results obtained from PKM activities are the use of a chip dough grinding machine in the production process, the new packaging design by including the MUI halal logo, increasing business owner's knowledge of the halal certification process and packaging design, as well as increasing skills in operating the grinding machine. The success of this activity can be measured by increasing the quantity of production from $6 \mathrm{~kg} / d a y$ to $14 \mathrm{~kg} /$ day or increasing by 150\%. Besides, product sales turnover rose 1.5-2 times compared to initial conditions.
\end{abstract}

Keywords: Grinding Machine; Cassava Chips; Halal; The Packaging

Submitted : 25 Juni 2019 Revision : 5 Oktober 2019 Accepted : 17 Februari 2020 


\section{PENDAHULUAN}

Bunda Mandiri merupakan UKM yang membuat keripik singkong mix sayur dengan merek "Singtoss". Usaha ini beralamatkan di Desa Karangwidoro, Kecamatan Dau, Kabupaten Malang. Rata-rata produksi sebanyak 5-6 kg per hari dan mencapai 10-12 $\mathrm{kg} /$ hari pada saat menjelang lebaran. Keripik singkong dijual dengan ukuran kemasan 100 dan 500 gram dan varian rasa sebanyak 6 . Pemasaran masih terbatas dengan mengandalkan agen-agen dan sampai saat ini keripik singkong sudah didistribusikan di Malang, Surabaya, Bandung, dan beberapa daerah lain.

Permasalahan dalam bidang produksi yang dihadapi oleh pemilik usaha keripik singkong adalah lamanya waktu proses pemipihan adonan dengan menggunakan mesin penggilingan yang ada saat ini. Hal ini disebabkan usaha tersebut masih menggunakan mesin manual dengan menggunakan tenaga manusia untuk menggerakkan mesin tersebut. Setelah itu pemotongan adonan yang telah ditipiskan juga masih dilakukan secara manual. Untuk memproduksi sebanyak 5-6 kg keripik singkong dalam seharinya, maka dibutuhkan waktu sekitar 4-5 jam untuk mencetak adonan melalui kegiatan pemipihan dan pemotongan adonan. Dengan kata lain, kapasitas produksi masih relatif kecil sehingga pemilik belum bisa memenuhi permintaan pasar.

Dari aspek pemasaran, pemilik usaha ingin meningkatkan pemasaran produknya dengan memiliki keunggulan berupa jaminan halal dari MUI. Dengan mencantumkan label halal pada kemasan maka peluang UKM menjual produk ke toko-toko akan lebih besar, karena sebagian besar toko mensyaratkan bahwa produk makanan dan minuman harus mencantumkan PIRT dan halal MUI. Tentunya mudah dipahami, saat ini konsumen semakin sadar bahwa makanan dan minuman yang dibeli haruslah sehat, aman, dan halal, sehingga konsumen akan tenang jika tulisan atau logo halal MUI tercantum pada label kemasan. Syafrina (2016) menyatakan bahwa manfaat sertifikat halal pada produk adalah memberikan perlindungan dan kepastian hukum hak-hak konsumen muslim terhadap produk yang tidak halal. Namun, pandangan yang ada saat ini adalah pengurusan sertifikasi halal membutuhkan biaya yang cukup mahal, waktu yang lama, serta prosedur yang rumit sampai sertifikat halal diterbitkan oleh LPPOM MUI. Hal ini juga dirasakan oleh pemilik usaha Bunda Mandiri, karena masih minimnya informasi mengenai prosedur mendapatkan sertifikasi halal.

Berdasarkan permasalahan pada aspek produksi dan pemasaran maka perlu adanya upaya inovasi teknologi dalam produk dan proses produksi. Bigliardi et al. (2011) menyatakan bahwa inovasi produk, proses dan pemasaran merupakan jenis inovasi yang banyak berlaku pada usaha kecil. Oleh karena itu tujuan program kegiatan pengabdian masyarakat (PKM) ini adalah melakukan inovasi dan difusi teknologi pada proses produksi untuk mempercepat waktu pemipihan adonan keripik singkong dan meningkatkan pemasaran produk dengan menciptakan keunggulan melalui produk halal.

Bunda Mandiri merupakan UKM yang membuat keripik singkong mix sayur dengan merek "Singtoss". Usaha ini beralamatkan di Desa Karangwidoro, Kecamatan Dau, Kabupaten Malang. Rata-rata produksi sebanyak 5-6 kg per hari dan mencapai 10-12 $\mathrm{kg} / \mathrm{hari}$ pada saat menjelang lebaran. Keripik singkong dijual dengan ukuran kemasan 100 dan 500 gram dan varian rasa sebanyak 6 . Pemasaran masih terbatas dengan mengandalkan agen-agen dan sampai saat ini keripik singkong sudah didistribusikan di Malang, Surabaya, Bandung, dan beberapa daerah lain.

Permasalahan dalam bidang produksi yang dihadapi oleh pemilik usaha keripik singkong adalah lamanya waktu proses pemipihan adonan dengan menggunakan mesin penggilingan yang ada saat ini. Hal ini disebabkan usaha tersebut masih menggunakan mesin manual dengan menggunakan tenaga manusia untuk menggerakkan mesin tersebut. Setelah itu pemotongan adonan yang telah ditipiskan juga masih dilakukan secara manual. Untuk memproduksi sebanyak 5-6 kg keripik singkong dalam seharinya, maka dibutuhkan waktu sekitar 4-5 jam untuk mencetak adonan melalui kegiatan pemipihan dan pemotongan adonan. Dengan kata lain, kapasitas produksi masih relatif kecil sehingga pemilik belum bisa memenuhi permintaan pasar.

Dari aspek pemasaran, pemilik usaha ingin meningkatkan pemasaran produknya dengan memiliki keunggulan berupa jaminan 
halal dari MUI. Dengan mencantumkan label halal pada kemasan maka peluang UKM menjual produk ke toko-toko akan lebih besar, karena sebagian besar toko mensyaratkan bahwa produk makanan dan minuman harus mencantumkan PIRT dan halal MUI. Tentunya mudah dipahami, saat ini konsumen semakin sadar bahwa makanan dan minuman yang dibeli haruslah sehat, aman, dan halal, sehingga konsumen akan tenang jika tulisan atau logo halal MUI tercantum pada label kemasan. Syafrina (2016) menyatakan bahwa manfaat sertifikat halal pada produk adalah memberikan perlindungan dan kepastian hukum hak-hak konsumen muslim terhadap produk yang tidak halal. Namun, pandangan yang ada saat ini adalah pengurusan sertifikasi halal membutuhkan biaya yang cukup mahal, waktu yang lama, serta prosedur yang rumit sampai sertifikat halal diterbitkan oleh LPPOM MUI. Hal ini juga dirasakan oleh pemilik usaha Bunda Mandiri, karena masih minimnya informasi mengenai prosedur mendapatkan sertifikasi halal.

Berdasarkan permasalahan pada aspek produksi dan pemasaran maka perlu adanya upaya inovasi teknologi dalam produk dan proses produksi. Bigliardi et al. (2011) menyatakan bahwa inovasi produk, proses dan pemasaran merupakan jenis inovasi yang banyak berlaku pada usaha kecil. Oleh karena itu tujuan program kegiatan pengabdian masyarakat (PKM) ini adalah melakukan inovasi dan difusi teknologi pada proses produksi untuk mempercepat waktu pemipihan adonan keripik singkong dan meningkatkan pemasaran produk dengan menciptakan keunggulan melalui produk halal.

\section{METODE}

Metode pelaksanaan kegiatan PKM melalui difusi teknologi proses produksi dan pengemasan produk serta advokasi dalam bentuk pendampingan pengajuan sertifikasi halal dan pengoperasian mesin. Mitra yang terlibat dalam kegiatan PKM ini adalah pengelola usaha Bunda Mandiri sebanyak 2 orang. Selama kegiatan pengabdian, mitra terlibat aktif dalam kegiatan pengajuan sertifikasi halal dengan mengisi formulir, mempersiapkan dan melaksanakan audit halal oleh MUI. Selain itu, mitra juga terlibat aktif dalam pendampingan pengoperasian mesin penggiling dengan memberikan informasi kelemahan-kelemahan selama digunakan sehingga mesin penggiling selanjutnya bisa digunakan dalam kondisi yang terbaik. Mitra juga memberikan masukan-masukan berkaitan dengan label kemasan sehingga kemasan produk yang baru bisa diluncurkan ke pasar. Peran terakhir yang diberikan oleh mitra adalah memberikan data-data kuantitatif terkait dengan kapasitas produksi dan omzet penjualan sebagai tolak ukur keberhasilan kegiatan pengabdian ini. Metode pelaksanaan kegiatan PKM dapat diuraikan secara detail sebagai berikut:

1. Difusi teknologi proses produksi dengan membuat mesin penggiling semi otomatis untuk memipihkan dan memotong adonan keripik secara sekaligus. Penelitian terdahulu yang terkait dengan desain mesin pemipih mengacu pada beberapa penelitian terdahulu yang dilakukan oleh Rahadi (2012), Setiawan (2015), dan Hansyah (2015). Setelah mesin selesai dibuat, selanjutnya dilakukan uji coba untuk mengetahui performansi mesin tersebut. Perbaikan-perbaikan akan dilakukan jika hasil performansi belum sesuai yang diharapkan.

2. Advokasi dalam bentuk pendampingan pengoperasian mesin penggiling adonan keripik singkong kepada mitra pengabdian. Setelah mesin diserahkan kepada mitra pengabdian maka dilakukan pendampingan selama 2 bulan untuk melihat kelemahan-kelemahan mesin selama digunakan untuk melakukan proses produksi dan memastikan mitra mampu mengoperasikan mesin dengan baik dan benar.

3. Advokasi dalam bentuk pendampingan pengajuan sertifikasi halal ke LPPOM MUI Jawa Timur.

4. Difusi teknologi pengemasan produk dengan membuat desain ulang kemasan keripik singkong "Singtoss" dengan tujuan menciptakan keunggulan melalui kemasan yang menarik dan jaminan halal MUI sehingga mampu meningkatkan pemasaran produk. 


\section{HASIL DAN PEMBAHASAN}

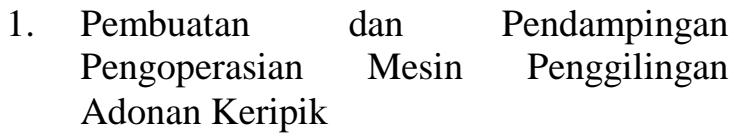

Mesin penggiling yang saat ini digunakan untuk memipihkan adonan keripik menggunakan mesin penggiling mie. Dimana mesin hanya berfungsi memipihkan adonan keripik menjadi lembaran memanjang dengan ketebalan tertentu. Mesin ini digerakkan dengan tenaga manusia dengan cara memutar engkol yang terhubung pada poros pemipih, seperti ditunjukkan pada Gambar 1. Selanjutnya adonan yang telah dipipihkan dipotong secara manual. Dengan kata lain kegiatan pemipihan dan pemotongan adonan keripik belum dilakukan dalam satu konstruksi mesin.

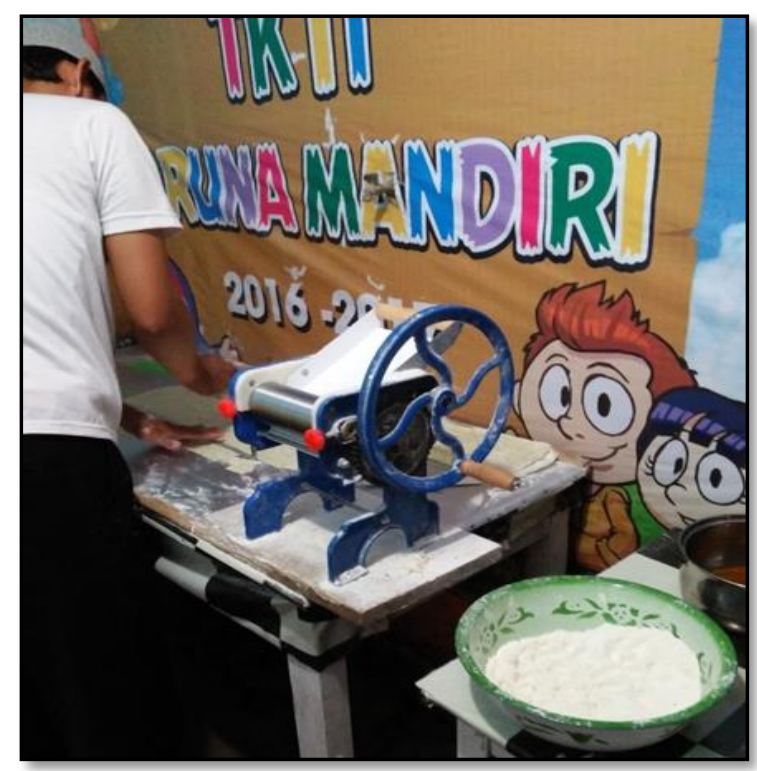

Gambar 1. Mesin penggiling adonan saat ini

Berdasarkan hasil FGD, mesin penggiling semi otomatis yang akan dibuat adalah mesin pemipih sekaligus pemotong adonan keripik. Mesin ini berfungsi menekan adonan menjadi bentuk pipih kemudian memotong sehingga membentuk keripik dengan dimensi yang telah ditentukan dan profilnya berbentuk persegi panjang. Mesin digerakkan dengan tenaga motor dan dirancang dalam satu konstruksi mesin dengan dimensi yang akan disesuaikan sehingga dapat meningkatkan efisiensi pengggunaannya.
Prinsip kerja mesin pemipih dan pemotong keripik singkong ini adalah motor listrik yang terhubung dengan poros penghubung akan memindahkan putaran sehingga memutar poros yang menekan adonan menjadi pipih.

Adonan kemudian akan masuk kedalam poros pemotong sehingga akan terpotong dengan dimensi yang telah ditentukan. Ketebalan adonan saat dipipihkan dapat diatur dengan memutar poros pengatur tekanan sehingga jarak antara poros pemipih akan menjadi lebih rapat dan dimensi adonan akan menjadi lebih tipis. Setelah mesin dibuat maka dilanjutkan dengan uji coba performansi. Dari hasil uji coba, kecepatan putaran perlu disesuaikan kembali agar keluarnya potongan adonan menjadi lebih lambat sehingga tidak terjadi tumpukan hasil. Gambar 2 menunjukkan mesin penggiling semi otomatis yang diberikan kepada mitra pengabdian.

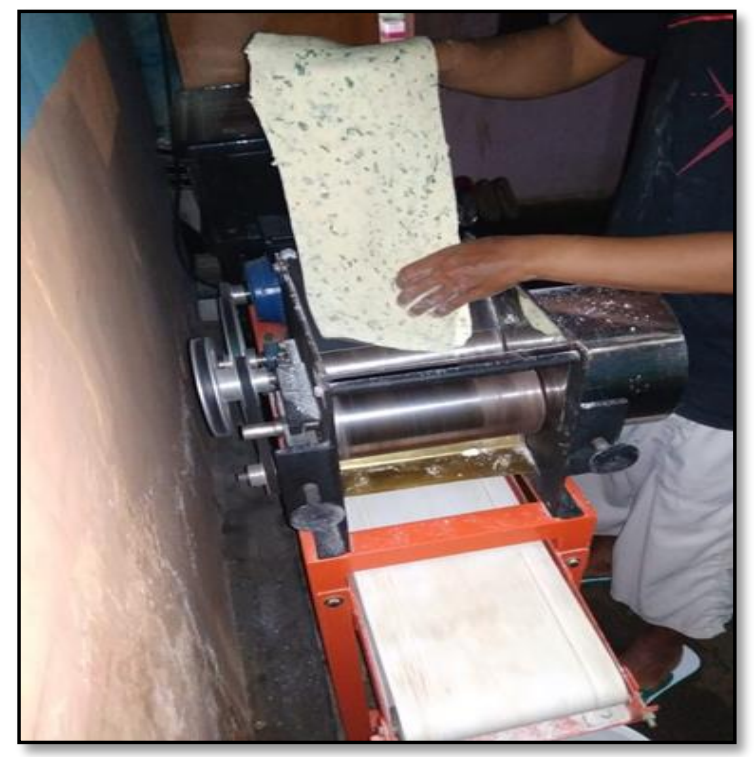

Gambar 2. Mesin penggiling adonan hasil difusi teknologi proses produksi pada UKM

Pelatihan dan pendampingan memberikan pengaruh secara sigfinikan terhadap tingkat pengetahuan dan pengetahuan yang dimiliki dapat diterapkan dalam kehidupan sehari-hari (Anggoro dkk., 2018). Sehingga langkah selanjutnya adalah melakukan pelatihan penggunaan mesin penggilingan kepada pemilik usaha dengan memberikan informasi yang sejelas-jelasnya mengenai cara pengoperasian mesin secara baik dan benar. 
Hal ini sejalan dengan pernyataan Prasanti dan Fuady (2017) yaitu kegiatan pelatihan merupakan salah satu media untuk menyampaikan informasi yang efektif. Setelah dilakukan pelatihan, maka mesin diserahterimakan kepada mitra pengabdian dan selanjutnya akan digunakan untuk membantu proses produksinya Berikutnya dilakukan pendampingan dengan kunjungan secara periodik dan komunikasi secara intens selama 2 bulan untuk memastikan bahwa mitra pengabdian menggunakan mesin dengan baik dan benar serta membantu jika ada kendalakendala dalam pengoperasian mesin tersebut.

Dari hasil pendampingan pengoperasian mesin penggiling adonan keripik maka ketrampilan pemilik usaha dalam mengoperasikan mesin menjadi sangat baik terbukti kualitas cetakan adonan sangat bagus di akhir-akhir periode pendampingan. Hasil lain yang diperoleh dengan difusi teknologi proses penggilingan maka waktu pencetakan adonan bisa dipersingkat. Dengan jam kerja 7 jam/hari, rata-rata kapasitas produksi meningkat dari 6 $\mathrm{kg} /$ hari menjadi $14 \mathrm{~kg} / \mathrm{hari}$ atau naik $150 \%$. Peningkatan ini memberikan dampak positif bagi pemilik usaha karena selama ini mereka sering tidak mampu memenuhi permintaan pasar dikarenakan keterbatasan tenaga kerja.pada analisis situasi atas persoalan yang dihadapi oleh pengrajin serta solusi yang ditawarkan guna menyelesaikan persoalan prioritas tersebut, dalam hal ini dilakukan dalam dua tahapan kegiatan meliputi identifikasi dan implementasi teknologi tepat guna dan pendampingan penglolaan usaha.

\section{Pendampingan pengajuan sertifikasi halal MUI}

Pengajuan sertifikasi halal ke LPPOM MUI melewati beberapa tahapan yaitu: 1) pendaftaran/penyerahan formulir sertifikasi halal, 2) pemeriksaan kelengkapan formulir/ dokumen sertifikasi halal, 3) pembayaran biaya sertifikasi halal, jika semua pemeriksaan dokumen telah lengkap, 4) audit pada UKM oleh Auditor yang ditunjuk oleh LPPOM MUI, 5) rapat fatwa MUI berdasarkan hasil audit, 6) tes laboratorium jika hasil rapat fatwa masih ragu kehalalannya, 7) penerbitan sertifikat halal (Lembaga Pengkajian Pangan Obat dan Kosmetika Majelis Ulama Indonesia, 2011).
Tim pengabdian melakukan pendampingan mulai dari pendaftaran sampai UKM memperoleh sertifikat halal.Langkah awal yang dilakukan tim PKM adalah membeli formulir pendaftaran sertifikasi halal ke LPPOM MUI Provinsi Jawa Timur di Surabaya. Selanjutnya tim PKM bertemu dengan mitra untuk menjelaskan cara-cara pengisian formulir pendaftaran tersebut dan menyelesaikan pengisian formulir. Selanjutnya tim pengabdian mengecek formulir yang telah diisi oleh mitra pengabdian apakah sudah lengkap dan benar. Hal-hal yang diisikan dalam formulir meliputi: 1) daftar produk yang diajukan sertifikasi halal, 2) data perusahaan, 3) daftar bahan yang digunakan dalam proses produksi, dan 4) daftar aplikasi bahan, dan Manual SJH. Formulir diisi rangkap 3 dengan dilampiri persyaratan-persyaratan yang telah ditetapkan (diantaranya foto copy KTP, PIRT, dan bagan alur proses produksi).

Setelah mitra pengabdian melengkapi dokumen pendaftaran sertifikasi halal maka tahap selanjutnya adalah mendaftarkan ke LPPOM MUI Provinsi Jawa Timur. UKM mendapat informasi dari LPPOM MUI mengenai jadwal auditing sertifikasi akan dilaksanakan pada hari Kamis tanggal 5 Juli 2018. Setelah mendapat kepastian maka mitra dan tim pengabdian berkoordinasi untuk melakukan persiapan audit halal. Hasil audit dinyatakan bahwa proses produksi tidak ditemukan hal-hal yang mencurigakan dan dinyatakan telah memenuhi persyaratan halal. Setelah menunggu sekitar 2 bulan dari audit halal maka pihak UKM menerima informasi dari LPPOM MUI bahwa sertifikat sudah bisa diambil. Gambar 3 menunjukkan sertifikat halal yang telah diperoleh dari kegiatan PKM ini.

\section{Desain ulang kemasan keripik singkong "Singtoss"}

Fungsi kemasan adalah mewadahi dan melindungi produk dari kerusakan. Selain itu fungsi pengemasan pada produk pangan adalah sebagai identitas produk, dalam hal ini kemasan dapat digunakan sebagai alat komunikasi dan informasi kepada konsumen melalui label yang terdapat pada kemasan (Julianti dan Nurminah, 2006). Saat ini dengan persaingan dunia usaha yang semakin tajam dan penjual saling berlomba untuk merebut perhatian calon pembeli maka bentuk dan model kemasan 
sangat penting peranannya dalam strategi pemasaran (Mukhtar dan Nurif, 2015). Oleh karena itu, kemasan harus mampu menarik perhatian dan menggambarkan keistimewaan produk sehingga calon pembeli tertarik.

Salah satu bagian dari kemasan adalah label. Label biasanya terbuat dari kertas atau film plastik dengan atau tanpa tambahan perekat, label dapat mencakup seluruh kemasan atau hanya setempat. Label harus mampu menjelaskan beberapa hal mengenai produk, siapa yang membuat, dimana dibuat, kapan dibuat, komposisi produk dan bagaimana produk tersebut digunakan. Sehingga beberapa hal yang harus dicantumkan pada saat mendesain label kemasan adalah (Mukhtar dan Nurif, 2015): nama produk, komposisi, isi/netto, nama dan alamat pembuat produk, nomor PIRT dan BPOM (jika ada), info halal, kode produksi, tanggal kadaluarsa, petunjuk cara penggunaan, dan nilai gizi.

Bersamaan dengan penyerahan sertifikat halal MUI maka tim pengabdian melakukan diskusi dengan pihak UKM mengenai desain ulang kemasan keripik singkong mix sayur "Sing Toss". Ukuran label kemasan saat ini adalah 7 x 10,5 cm seperti ditunjukkan pada Gambar 3.

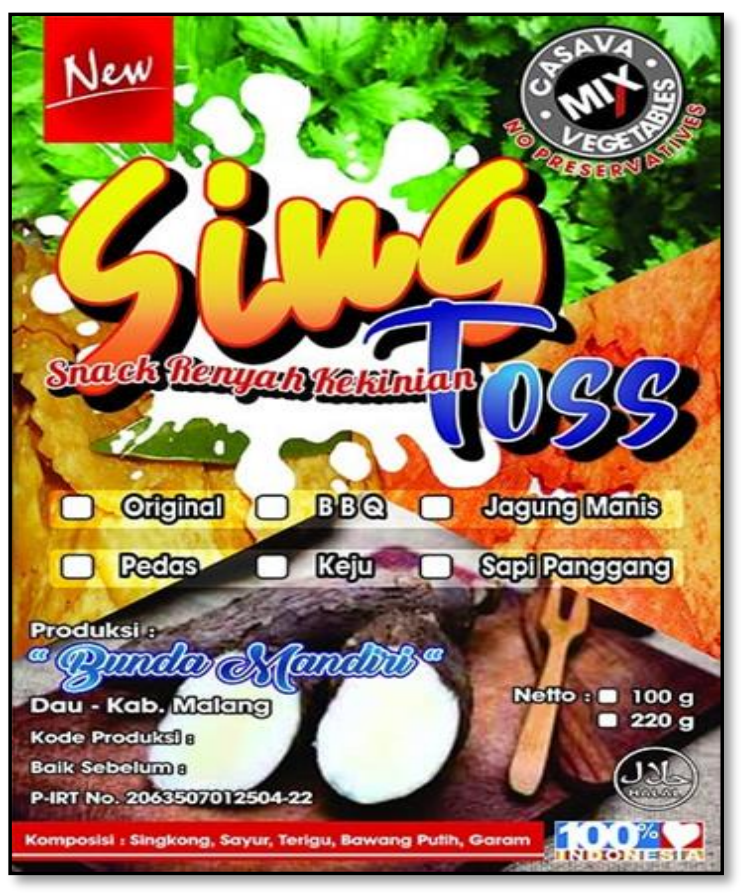

Gambar 3. Label Kemasan Lama
Dari hasil diskusi, pihak UKM menginginkan label kemasan yang lebih minimalis tampilannya dan warna yang tidak terlalu mencolok. Selain itu, label akan mencatumkan logo halal MUI sehingga menjadi tambahan keunggulan dari produk ini. Tulisan "Casava" dibetulkan menjadi "Cassava" yang artinya singkong. Selanjutnya "Cassava Mix Vegetables" dirubah menjadi "Cassava Mix Veggie Chips" untuk menekankan bahwa produknya adalah keripik singkong dengan campuran sayur. Penulisan dengan bahasa Inggris karena segmen yang ditarget adalah kaum muda. Usulan lain adalah label kemasan setiap rasa keripik dibuat berbeda sehingga memudahkan pembeli memilih rasa yang diinginkan. Tim PKM membuat beberapa alternatif desain label kemasan dengan mengacu literatur-literatur yang telah dipelajari sebelumnya. Selanjutnya tim PKM menunjukkan beberapa alternatif tersebut dan kemudian melakukan diskusi dengan pihak UKM untuk menentukan desain label yang akan digunakan. Selanjutnya desain label dicetak dan mulai digunakan oleh UKM pada saat mengemas produk keripik singkong mix sayur. Gambar 4 menunjukkan desain label kemasan "SingToss" yang baru untuk varians pedas.

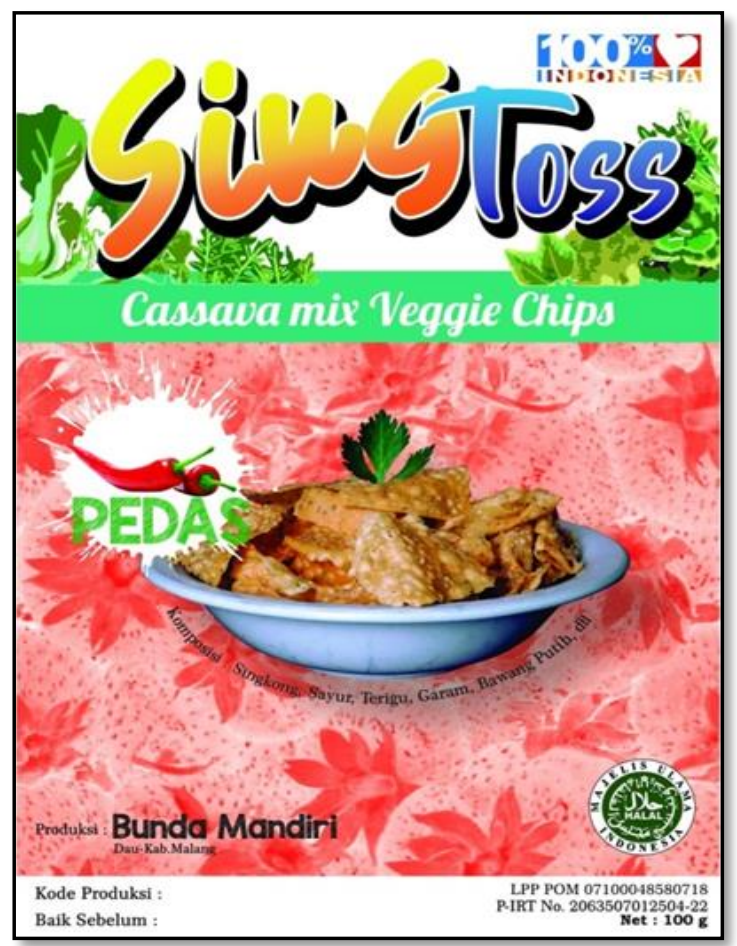

Gambar 4. Label Kemasan Baru 
Hidayat (2011) menyatakan ketika sebuah makanan ringan yang dihasilkan UKM dikemas dengan plastik akan berbeda ketika dikemas menggunakan alumunium foil yang kesannya menyerupai makanan olahan dari pabrik. Hal ini menunjukan bahwa tampilan visual dari sebuah kemasan atau estetika produk akan sangat mempengaruhi ketertarikan seseorang pada saat membeli produk. Berdasarkan pertimbangan tersebut maka tim PKM mengusulkan untuk menggunakan alumunium foil sebagai bahan kemasan agar kemasan yang dimiliki menjadi lebih menarik lagi dengan tampilan label yang baru.

Dari hasil pendampingan penga-juan sertifikasi halal MUI maka pengetahuan pemilik usaha mengenai prosedur dan tata cara pengajuan sertifikasi halal MUI menjadi baik sehingga jika pemilik melakukan diversifikasi produk maka bisa mengajukan sertifikasi sendiri. Selain itu pengetahuan dan ketrampilan pemilik usaha mengenai pengemasan produk juga memingkat berdasarkan pengalaman dari kegiatan PKM ini. Selain itu, hasil yang diperoleh dengan desain ulang kemasan produk maka omzet penjualan produk meningkat antara 1,5-2 kali lipat dibandingkan kondisi awal karena banyak pembeli yang tertarik dengan melihat kemasan baru.

\section{SIMPULAN}

Kegiatan PKM ini menghasilkan : 1) penggunaan mesin penggiling adonan keripik dalam proses produksi, 2) Adanya desain kemasan yang baru dengan mencantumkan logo halal MUI, 3) peningkatan pengetahuan pemilik usaha mengenai proses sertifikasi halal dan desain kemasan, 4) peningkatan ketrampilan dalam mengoperasikan mesin penggiling.

\section{UCAPAN TERIMA KASIH}

Ucapan terimakasih kepada Universitas Muhammadiyah Malang yang memberikan dukungan dalam pelaksanaan Program Kemitraan Masyarakat (PKM) ini.

\section{DAFTAR PUSTAKA}

Anggoro, S., Harmianto, S., \& Yuwono, P. D. (2018). Upaya Meningkatkan Kemampuan Pedagogik Guru Melalui Pelatihan Pembelajaran Te matik Sains Menggunakan Inquiry Learning Process dan Science Activity Based Daily Life. Jurnal Pengabdian dan Pemberdayaan Masyarakat, 2 (1), 2935.

Bigliardi, B., Pierluigi, C., \& Dormio, A. I. (2011). Innovative Caharcteristics of Small and Medium Enterprises. Journal of Technology Management \& Innovation, 6 (22), 83-93.

Hansyah, A. (2015). Perancangan Mie Pasta dengan Kapasitas $5 \mathrm{~kg} /$ menit, Tugas Akhir, Fakultas Teknik, Universitas Nusantara Persatuan Guru Republik Indonesia.

Hidayat, M.J. (2011). Tinjauan Kognisi Desain Produk Kemasan Sebagai Unsur Identitas Budaya Populer Atas Produk Kemasan Makanan Industri Kecil Menengah (IKM). Kawistara. 1(3), 244-256.

Julianti, E., \& Nurminah, M. (2006). Teknologi Pengemasan. Fakultas Pertanian, Universitas Sumatera Utara.

Lembaga Pengkajian Pangan Obat dan Kosmetika Majelis Ulama Indonesia, (2011). Tata Cara Berproduksi Produk Halal untuk Usaha Kecil dan Mikro, Diakses dari http://jambil. kemenag.go.id/file/media/BORANGU KM.pdf.

Mukhtar, S. \& Nurif, M. (2015). Peranan Packaging dalam Meningkatkan Hasil Produksi Terhadap Konsumen, Jurnal Sosial Humaniora, 8(2), 181-191.

Prasanti, D. \& Fuady, I. (2017). Penyuluhan Program Literasi Informasi Kesehatan dalam Meningkatkan Kualitas Sanitasi Bagi Masyarakat di Kaki Gunung Burangrang Kab. Bandung Barat. 
Jurnal Pengabdian dan Pemberdayaan Masyarakat, 1 (2), 129-138.

Rahadi, A.S.T. (2012). Perancangan Mesin Pemipih dan Pemotong Adonan Mie, Tugas Akhir, Teknik Mesin, Universitas Negeri Yogyakarta.
Setiawan, B.D., (2015). Perancangan Mesin Pemipih dan Pemotong Adonan Mie, Tugas Akhir, Teknik Mesin, Universitas Wijaya Putra. 